\title{
Subclinical hypothyroidism and the risk of cancer incidence and cancer mortality: a systematic review
}

Juan Gómez-Izquierdo ${ }^{1}$, Kristian B. Filion ${ }^{2,3,4}$, Jean-François Boivin ${ }^{3,4}$, Laurent Azoulay ${ }^{2,3,5}$, Michael Pollak ${ }^{6,7}$ and Oriana Hoi Yun $\mathrm{Yu}^{3,8^{*}}$ (D)

\begin{abstract}
Background: Thyroid hormone has been shown to be involved in carcinogenesis via its effects on cell proliferation pathways. The objective of this study is to determine the association between subclinical hypothyroidism (SCH) and the risk of incident cancer and cancer mortality via systematic review.

Methods: A systematic search was performed on Medline and Pubmed to identify relevant studies. Randomized controlled trials, and observational studies assessing $\mathrm{SCH}$ or its treatment and the risk of incident cancer or cancer mortality were identified.

Results: A total of 7 cohort and 2 case-control studies met our inclusion criteria. In general, these studies were of medium to good quality. Overall, studies revealed no association between SCH and breast and prostate cancer. One study found that untreated SCH may be associated with an increased risk of colorectal cancer (adjusted odds ratio [OR]: 1.16; 95\% confidence interval [CI]: 1.08-1.24). One study showed an increased risk in thyroid cancer incidence (adjusted OR: 3.38; 95\% Cl: 2.05-5.59) associated with elevation of a thyroid stimulating hormone (TSH) of $>1.64 \mathrm{mIU} / \mathrm{L}$. Two studies found an increase in cancer mortality among patients with SCH compared to euthyroid individuals; in contrast one study found no association between subclinical hypothyroidism and cancer mortality among aging men.

Conclusion: The number of studies examining thyroid dysfunction and cancer risk and mortality is limited. Future studies assessing the association between thyroid dysfunction and cancer risk and mortality are needed, which will further address the need to treat subclinical hypothyroidism.
\end{abstract}

Keywords: Subclinical hypothyroidism, Cancer, Systematic review, Mortality

\footnotetext{
* Correspondence: hoi.yu@mcgill.ca

${ }^{3}$ Center for Clinical Epidemiology, Lady Davis Institute, Jewish General

Hospital, 3755 Côte Sainte-Catherine, H-425, Montreal, Quebec H3T 1E2,

Canada

${ }^{8}$ Division of Endocrinology, Department of Medicine, Jewish General

Hospital, Montreal, Quebec, Canada

Full list of author information is available at the end of the article
}

C C The Author(s). 2020 Open Access This article is licensed under a Creative Commons Attribution 4.0 International License, which permits use, sharing, adaptation, distribution and reproduction in any medium or format, as long as you give appropriate credit to the original author(s) and the source, provide a link to the Creative Commons licence, and indicate if changes were made. The images or other third party material in this article are included in the article's Creative Commons licence, unless indicated otherwise in a credit line to the material. If material is not included in the article's Creative Commons licence and your intended use is not permitted by statutory regulation or exceeds the permitted use, you will need to obtain permission directly from the copyright holder. To view a copy of this licence, visit http://creativecommons.org/licenses/by/4.0/. The Creative Commons Public Domain Dedication waiver (http://creativecommons.org/publicdomain/zero/1.0/) applies to the data made available in this article, unless otherwise stated in a credit line to the data. 


\section{Background}

The relationship between thyroid function and cancer has been a subject of debate for more than 200 years, with studies showing conflicting results $[1,2]$. In vitro studies have shown that thyroid hormones not only regulate body metabolism but they also play an important role in cell proliferation and differentiation in normal tissues [3]. Thyroid hormones consist of thyroxine (T4) and triiodothyronine (T3), which is the active form of the thyroid hormone. Both enter cells via transporter proteins whereby $\mathrm{T} 4$ becomes converted to $\mathrm{T} 3$ by deiodinases. T3 subsequently binds to thyroid hormone receptors, which then forms heterodimers with the retinoid $\mathrm{X}$ receptor (RXR) to induce transcription of a number of target genes with thyroid response elements [3].

Subclinical hypothyroidism $(\mathrm{SCH})$ is a form of thyroid dysfunction that is highly prevalent, with a reported prevalence of 5 to $10 \%$ of the population worldwide [4]. $\mathrm{SCH}$ is defined by elevated thyroid stimulating hormone (TSH) levels with normal T4 levels. Given that the T4 level is within normal range, patients with $\mathrm{SCH}$ usually do not experience hypothyroid symptoms. However, given that studies have shown an increased risk of heart failure associated with $\mathrm{SCH}$ whereby the TSH levels are $>10 \mathrm{mIU} / \mathrm{L}$ [5], it is recommended that patients with $\mathrm{SCH}$ and this extent of TSH elevation receive levothyroxine replacement [6]. Currently, there is no consensus as to whether patients with $\mathrm{SCH}$ with a TSH level of < $10 \mathrm{mIU} / \mathrm{L}$ should be treated with levothyroxine as there is uncertainty regarding the clinical benefits of therapy in these cases. According to some studies, less than 50\% of patients with $\mathrm{SCH}$ receive hormone replacement [7].

Given that thyroid hormone has been shown to play a role in cancer pathogenesis, further studies assessing the association between thyroid dysfunction and its effects on carcinogenesis are needed. This is particularly true for $\mathrm{SCH}$, where the clinical benefits of levothyroxine treatment are unclear. The objective of this study is therefore to determine the influence of thyroid dysfunction, namely $\mathrm{SCH}$, on cancer incidence and cancer mortality via systematic review of the evidence available to date.

\section{Methods}

\section{Data source and searches}

A systematic search was performed on Ovid MEDLINE from the date of its inception until November 13th, 2017, combining words related to thyroid and cancer (MeSH and non- MeSH terms) to identify studies of thyroid dysfunction and incident cancer and those examining thyroid dysfunction and mortality in cancer patients (Appendix). A second search was performed using Pubmed from the date of its inception until March 12, 2020 (Appendix). No language limitations were used. In addition, we hand-searched the references of included studies to identify additional relevant studies that were not identified in our electronic search.

\section{Study selection}

Inclusion criteria comprised of randomized clinical trials assessing treatment of $\mathrm{SCH}$ with levothyroxine treatment, cohort and case-control studies reporting $\mathrm{SCH}$, where the thyroid dysfunction chronologically preceded the cancer incidence or mortality by at least a year to reduce the possibility of including studies with reverse causation, meaning that the cancer or its treatment induced the thyroid dysfunction and not the opposite [8]. Articles where the $\mathrm{SCH}$ was primary (not secondary to a medical treatment or procedure) were included. Articles reporting iatrogenic hypothyroidism, thyroid dysfunction during pregnancy or were medication induced were not included since the effect of these causes of $\mathrm{SCH}$ on cancer might have a different pathophysiology considering that $\mathrm{SCH}$ is commonly induced by an autoimmune mechanism [9, 10]. Exclusion criteria were studies using outdated methods to screen or diagnose thyroid dysfunction or cancer, suspected to have a high risk of bias (i.e. recall) according to the study methods, and studies in which the reference and comparison groups have cancer. Studies were screened by two investigators (J.G. and O.Y.) and discrepancies were resolved by a third investigator (K.B.F.).

\section{Data extraction and quality assessment}

Data were extracted using a pilot-tested form that included author, year of publication, study design, study period, sample size (overall and by group), type of population, age of the patients, source of the data or database used for the study, follow-up duration, objective of the study, if anti-thyroperoxidase antibodies (TPOAb) had been measured, effect measure, results (adjusted rates, survival times, and mortality rates), and conclusions.

Quality assessment was performed using the Cochrane tool to assess risk of bias in cohort studies [11] and the Newcastle-Ottawa quality assessment scale for case control studies [12]. Data extraction and quality analyses were completed independently by two authors (J.G. and O.Y.). Disagreements were resolved by discussion with a third independent reviewer (K.B.F.).

Meta-analysis was not possible due to the high heterogeneity in study designs, effect measures reported, and outcomes (cancer incidence, mortality, survival time). All the methods followed the PRISMA guidelines for systematic reviews of the literature $[13,14]$.

\section{Results}

Study selection

A total of 37,073 records were identified (Fig. 1); 36,954 were retrieved from Ovid MEDLINE, 117 were retrieved from Pubmed and 2 were retrieved from other sources 


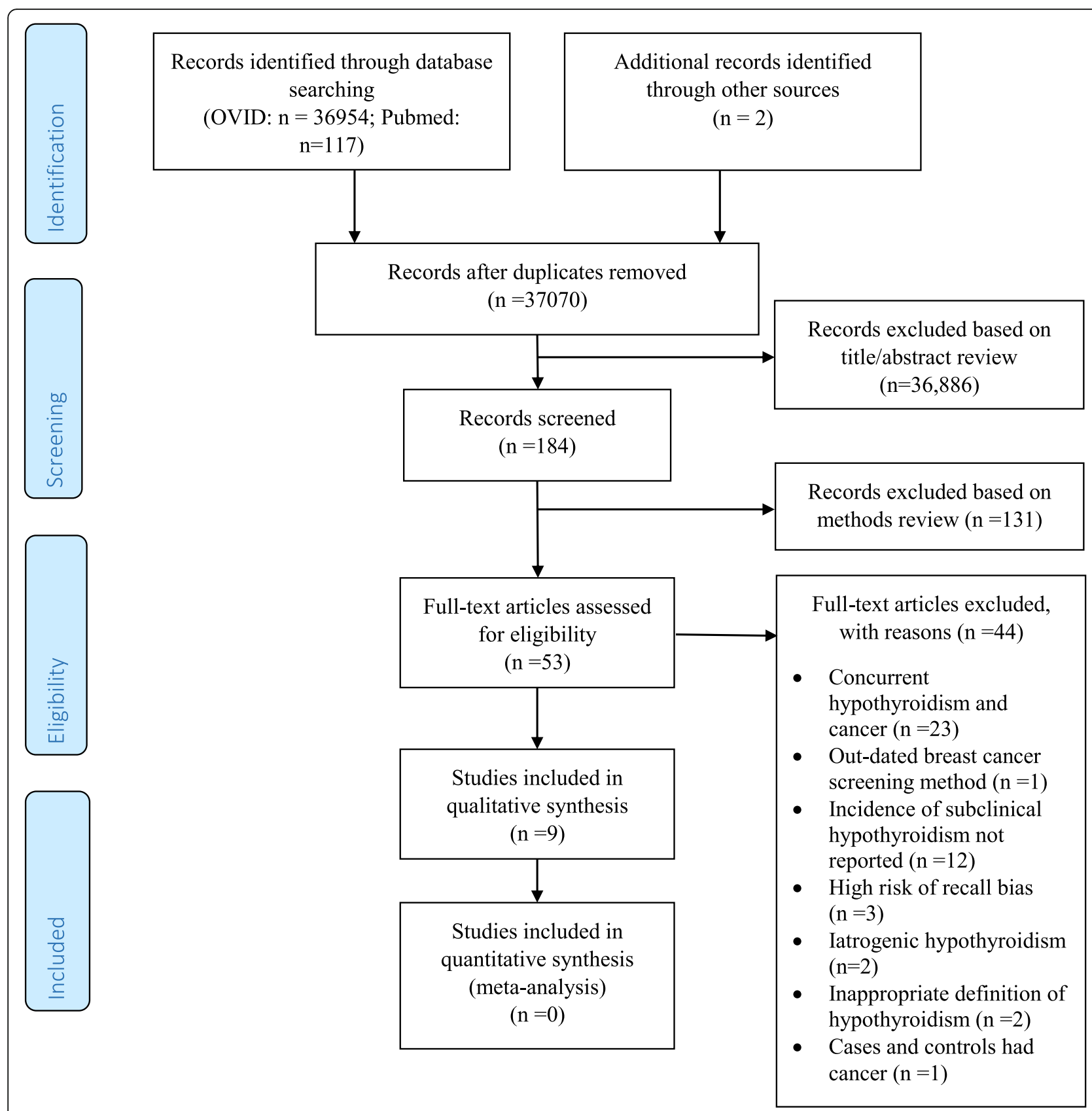

Fig. 1 PRISMA Flow Diagram showing the selection of studies assessing the association between subclinical hypothyroidism and cancer incident risk and cancer mortality. The flow diagram template was adapted from the 2009 PRISMA statement [14]

$[15,16]$ (cited in other articles obtained via our search). 36,886 articles were found non-relevant after screening the titles and abstracts. One hundred and eighty-four articles were screened via further assessment of the methods described and subsequently 53 articles were thoroughly reviewed for eligibility. Forty-four articles were excluded for the following reasons: 23 studies identified concurrent thyroid dysfunction and cancer (reverse causation cannot be excluded) [17-38], 1 study used an outdated method to screen for breast cancer (i.e. thermography) [39], 12 studies did not report SCH
[40-51], 3 studies have potential high risk of recall bias (no specific tool was applied to assess for risk of recall bias at this point; it was identified by the assessor after reading the methods of the article) [52-54], 2 studies included iatrogenic hypothyroidism [55, 56], 2 studies had an inappropriate definition of hypothyroidism (both defined hypothyroidism based on use of thyroid hormone replacement without reporting levels of TSH or T4) [57, 58], and 1 study involved cases and controls with a history of cancer at baseline [59]. A total of 9 studies were included in our systematic review. 


\section{Study characteristics}

The 9 included studies comprised of 2 case-control studies [7, 60], 3 retrospective cohort studies [16, 61, 62], and 4 prospective cohort studies $[8,15,63,64]$ (Tables 1 and 2). There were no randomized controlled trials identified that studied the effects of treatment of $\mathrm{SCH}$ on the risk of cancer or cancer mortality. One included study assessed the effect of SCH on colorectal cancer [7], one study on breast cancer [8], one study on prostate cancer [60], one on thyroid cancer [61] and one on hepatocellular carcinoma [62]. One study analyzed overall cancer incidence [15], and three studies focused on overall cancer mortality [16, 63, 64]. Two of these studies assessed cancer mortality as a secondary outcome $[16,64]$.

\section{Quality assessment}

Overall, the cohort studies had good quality (Table 3). The study by Fighera et al. [61] had high risk of bias because the exposed and non-exposed groups did not come from the same source population [61]. Also, it was not clear if $\mathrm{SCH}$ was identified prior to the cancer outcome [61]. Two studies did not fully adjust for confounder factors present in the exposed and non-exposed groups [16, 62]. Razvi et al. [16] assessed cancer mortality as a secondary outcome and the variables that were adjusted in the analyses were focused for cardiovascular outcomes. Finally, Pinter et al. [62] assessed the association between thyroid dysfunction and overall survival among patients with hepatocellular carcinoma. Unfortunately, the data collected for these patients lacked information on a number of potential confounders related to patient characteristics, including comorbidities.

Case control-studies had very good quality overall (Table 4). The identification of cases involved record linkage only to a primary care database in the study by Boursi et al. [7] without independent validation.

\section{Cancer incidence}

The risk of cancer incidence varied depending on the type of cancer studied. Hellevik et al. [15] found no association between hypothyroidism (i.e. inclusion of $\mathrm{SCH}$ and overt hypothyroidism) and overall cancer risk (patients with TSH $>3.5 \mathrm{mIU} / \mathrm{L}$, risk of all cancers adjusted hazards ratio [HR]: 0.96; 95\% CI: 0.82-1.12). In this study, individual cancer risks for the more common cancers were also assessed (i.e., lung, colon, prostate, and breast cancer). There were no observed increased risks

Table 1 Study characteristics of comparative studies evaluating subclinical hypothyroidism and cancer risk and mortality

\begin{tabular}{|c|c|c|c|c|c|c|}
\hline Study & Study design & $\mathrm{n}$ & Data origin & $\begin{array}{l}\text { Study } \\
\text { period }\end{array}$ & Population & Definition of SCH \\
\hline $\begin{array}{l}\text { Kuijpens } \\
2005[8]\end{array}$ & $\begin{array}{l}\text { Prospective } \\
\text { cohort }\end{array}$ & 2738 & $\begin{array}{l}\text { The Eindhoven Cancer } \\
\text { Registry }\end{array}$ & $\begin{array}{l}1994- \\
2003\end{array}$ & $\begin{array}{l}\text { All women between } 47 \text { and } 54 \text { years old living in the city } \\
\text { of Eindhoven were invited to participate in the Eindhoven } \\
\text { perimenopausal osteoporosis study. All women who did } \\
\text { not have breast cancer in } 1994 \text { were followed }\end{array}$ & $\begin{array}{l}\text { TSH }>6 \mathrm{mlU} / \mathrm{L} \text { and } \mathrm{T} 4 \\
\text { within normal range ( } 8 \\
\text { to } 26 \mathrm{pmol} / \mathrm{L})\end{array}$ \\
\hline $\begin{array}{l}\text { Hellevik } \\
2009 \\
{[15]}\end{array}$ & $\begin{array}{l}\text { Prospective } \\
\text { cohort }\end{array}$ & $\begin{array}{l}29 \\
691\end{array}$ & $\begin{array}{l}\text { Nord-Trøndelag Health } \\
\text { Study }\end{array}$ & $\begin{array}{l}1995- \\
2005\end{array}$ & $\begin{array}{l}\text { Participants completed questionnaire with thyroid } \\
\text { function tests drawn and were followed for cancer } \\
\text { incidence, defined using the Cancer Registry of Norway }\end{array}$ & $\begin{array}{l}\text { TSH } \\
>3.5 \mathrm{mIU} / \mathrm{L}\end{array}$ \\
\hline $\begin{array}{l}\text { Razvi } \\
2012 \\
{[16]}\end{array}$ & $\begin{array}{l}\text { Retrospective } \\
\text { cohort }\end{array}$ & 4735 & $\begin{array}{l}\text { United Kingdom } \\
\text { General Practitioner } \\
\text { Research Database }\end{array}$ & $\begin{array}{l}2011- \\
2009\end{array}$ & $\begin{array}{l}\text { Patients with incident subclinical hypothyroidism followed } \\
\text { for ischemic heart disease and all-cause mortality (cancer } \\
\text { mortality also assessed). }\end{array}$ & TSH 5.01 to $10 \mathrm{mlU} / \mathrm{L}$ \\
\hline $\begin{array}{l}\text { Mondul } \\
2012 \\
{[60]}\end{array}$ & Case-control & 1201 & $\begin{array}{l}\text { Alpha-Tocophenol, } \\
\text { Beta-Carotene Cancer } \\
\text { Prevention Study }\end{array}$ & $\begin{array}{l}1985- \\
1993\end{array}$ & $\begin{array}{l}\text { Prostate cancer patients diagnosed } 3 \text { years after baseline } \\
\text { matched with up to } 2 \text { controls }\end{array}$ & $\begin{array}{l}\mathrm{TSH}>3 \mathrm{mlU} / \mathrm{L} ; \mathrm{T} 4< \\
4.6 \mu \mathrm{g} / \mathrm{dL}\end{array}$ \\
\hline $\begin{array}{l}\text { Waring } \\
2012 \\
{[64]}\end{array}$ & $\begin{array}{l}\text { Prospective } \\
\text { study }\end{array}$ & 1337 & $\begin{array}{l}\text { Osteoporotic Fractures } \\
\text { in Men Study (MrOs) } \\
\text { Cohort }\end{array}$ & $\begin{array}{l}2000- \\
2011\end{array}$ & $\begin{array}{l}\text { Men } \geq 65 \text { years of age in six clinical centers in the United } \\
\text { States }\end{array}$ & $\begin{array}{l}\text { TSH above upper limit } \\
\text { of normal and }<10 \\
\mathrm{mU} / \mathrm{L}\end{array}$ \\
\hline $\begin{array}{l}\text { Fighera } \\
2015 \\
{[61]}\end{array}$ & $\begin{array}{l}\text { Retrospective } \\
\text { cohort }\end{array}$ & 622 & $\begin{array}{l}\text { Federal University of } \\
\text { Parana }\end{array}$ & $\begin{array}{l}1999- \\
2008\end{array}$ & $\begin{array}{l}\text { Patients with subclinical hypothyroidism with thyroid } \\
\text { nodules that had thyroidectomy versus fine needle } \\
\text { aspiration biopsy }\end{array}$ & $\begin{array}{l}\text { TSH was assessed as a } \\
\text { continuous variable }\end{array}$ \\
\hline $\begin{array}{l}\text { Boursi } \\
2015[7]\end{array}$ & $\begin{array}{l}\text { Nested case- } \\
\text { control }\end{array}$ & $\begin{array}{l}103, \\
044\end{array}$ & $\begin{array}{l}\text { The Health } \\
\text { Improvement Network } \\
\text { (THIN) }\end{array}$ & $\begin{array}{l}1995- \\
2013\end{array}$ & $\begin{array}{l}\text { Case patients identified in THIN with colorectal cancer } \\
\text { matched to up to } 4 \text { eligible control patients }\end{array}$ & $\mathrm{TSH}>4 \mathrm{mg} / \mathrm{dL}$ \\
\hline $\begin{array}{l}\text { Tseng } \\
2015 \\
{[63]}\end{array}$ & $\begin{array}{l}\text { Prospective } \\
\text { cohort }\end{array}$ & $\begin{array}{l}115 \\
746\end{array}$ & Taiwan & $\begin{array}{l}1998- \\
2008\end{array}$ & $\begin{array}{l}\text { Patients with no known thyroid disorders on medication } \\
\text { treatment that had a health examination in one of } 4 \\
\text { private nationwide MJ Health Screening Centers in } \\
\text { Taiwan, followed for cancer mortality }\end{array}$ & TSH 5 to $19.96 \mathrm{mlU} / \mathrm{L}$ \\
\hline $\begin{array}{l}\text { Pinter } \\
2017 \\
{[62]}\end{array}$ & $\begin{array}{l}\text { Retrospective } \\
\text { cohort }\end{array}$ & 667 & $\begin{array}{l}\text { Medical University of } \\
\text { Vienna }\end{array}$ & $\begin{array}{l}1992- \\
2013\end{array}$ & $\begin{array}{l}\text { Patients diagnosed with hepatocellular carcinoma with } \\
\text { thyroid function tests, followed for overall survival }\end{array}$ & Free $\mathrm{T} 4 \leq 1.66 \mathrm{ng} / \mathrm{dL}$ \\
\hline
\end{tabular}


Table 2 Effect estimates of cancer risk and mortality in studies comparing patients with untreated to treated subclinical hypothyroidism or euthyroidism

\begin{tabular}{|c|c|c|c|c|c|c|c|}
\hline Study & $\begin{array}{l}\text { Treated } \\
\text { SCH/ } \\
\text { euthyroid } \\
\text { (n) }\end{array}$ & $\begin{array}{l}\text { Untreated } \\
\text { SCH } \\
\text { (n) }\end{array}$ & $\begin{array}{l}\text { Effect } \\
\text { measure }\end{array}$ & $\begin{array}{l}\text { Point } \\
\text { estimate }\end{array}$ & $95 \% \mathrm{Cl}$ & TPOAb & Finding summary \\
\hline $\begin{array}{l}\text { Kuijpens } \\
2005[8]\end{array}$ & NA & NA & OR & 1.9 & $0.8-4.9$ & $\begin{array}{l}\text { More prevalent in women } \\
\text { with previous or current } \\
\text { diagnosis of breast cancer. }\end{array}$ & $\begin{array}{l}\text { There was no association between subclinical } \\
\text { hypothyroidism and the risk of breast cancer. } \\
\text { However, women with a history of breast cancer } \\
\text { were more likely to have anti-TPO antibodies. }\end{array}$ \\
\hline $\begin{array}{l}\text { Hellevik } \\
2009 \\
{[15]}\end{array}$ & 12,389 & 2149 & $H R$ & 0.96 & $\begin{array}{l}0.82- \\
1.12\end{array}$ & NA & $\begin{array}{l}\text { There was no association between the risk of } \\
\text { overall cancer incidence and TSH level of }>3.5 \mathrm{mIU} / \\
\mathrm{L} \text {. }\end{array}$ \\
\hline $\begin{array}{l}\text { Mondul } \\
2012 \\
{[60]}\end{array}$ & $\begin{array}{l}800 \\
\text { prostate } \\
\text { cancer } \\
\text { patients }\end{array}$ & $\begin{array}{l}401 \\
\text { controls }\end{array}$ & OR & 0.71 & $\begin{array}{l}0.47- \\
1.06\end{array}$ & NA & $\begin{array}{l}\text { Men with elevated TSH levels were associated with } \\
\text { a decreased risk of prostate cancer. }\end{array}$ \\
\hline $\begin{array}{l}\text { Razvi } \\
2012 \\
{[16]}\end{array}$ & $\begin{array}{l}1634 \text { (age } \\
40-70) ; \\
819 \text { (age > } \\
70)\end{array}$ & $\begin{array}{l}\text { 1459(age } \\
40-70) \text {; } \\
823 \text { (age > } \\
70)\end{array}$ & $H R$ & $\begin{array}{l}0.59 \\
\text { (age } \\
40-70 \text { ) } \\
0.51 \\
\text { (age > } \\
70 \text { ) }\end{array}$ & $\begin{array}{l}0.21- \\
0.99 \\
\text { (age } \\
40-70 \text { ) } \\
0.24- \\
1.09 \\
\text { (age > } \\
70)\end{array}$ & NA & $\begin{array}{l}\text { Treatment of SCH was associated with a decreased } \\
\text { risk of cancer mortality among adults age } 40 \text { to } 70 \\
\text { years. }\end{array}$ \\
\hline $\begin{array}{l}\text { Waring } \\
2012 \\
{[64]}\end{array}$ & $\begin{array}{l}1248 \text { (men } \\
\text { age } \geq 65)\end{array}$ & $\begin{array}{l}89 \text { (men } \\
\text { age } \geq 65)\end{array}$ & $\mathrm{RH}$ & 0.88 & $\begin{array}{l}0.44- \\
1.74\end{array}$ & NA & $\begin{array}{l}\text { Subclinical hypothyroidism was not associated with } \\
\text { cancer mortality among men } \geq 65 \text { years of age. }\end{array}$ \\
\hline $\begin{array}{l}\text { Boursi } \\
2015[7]\end{array}$ & $\begin{array}{l}20,990 \\
\text { colorectal } \\
\text { cancer } \\
\text { patients }\end{array}$ & $\begin{array}{l}82,054 \\
\text { controls }\end{array}$ & OR & 1.16 & $\begin{array}{l}1.08- \\
1.24\end{array}$ & NA & $\begin{array}{l}\text { SCH was associated with an increased risk of } \\
\text { colorectal cancer. }\end{array}$ \\
\hline $\begin{array}{l}\text { Fighera } \\
2015 \\
{[61]}\end{array}$ & NA & NA & OR & 2.57 & $\begin{array}{l}1.41- \\
4.70\end{array}$ & NA & $\begin{array}{l}\text { Risk of thyroid carcinoma increased with increasing } \\
\text { TSH levels above } 1.64 \mathrm{mIU} / \mathrm{L} \text {. }\end{array}$ \\
\hline $\begin{array}{l}\text { Tseng } \\
2015 \\
{[63]}\end{array}$ & 113,905 & 1841 & RR & 1.51 & $\begin{array}{l}1.06- \\
2.15\end{array}$ & NA & $\begin{array}{l}\mathrm{SCH} \text { was associated with an increased risk of cancer } \\
\text { mortality. }\end{array}$ \\
\hline $\begin{array}{l}\text { Pinter } \\
2017 \\
{[62]}\end{array}$ & 548 & 69 & $H R$ & 2.1 & $1.3-3.3$ & NA & $\begin{array}{l}\text { Higher free thyroxine levels (i.e. }>1.66 \text { vs. } \leq 1.66 \mathrm{ng} / \\
\text { dl) was associated with a higher overall survival of } \\
\text { patients with HCC. }\end{array}$ \\
\hline
\end{tabular}

Abbreviations: $n$ number of individuals, $C l$ confidence interval, TPOAb anti- thyroperoxidase antibodies, NA not available, TSH thyroid stimulating hormone, $H R$ hazard ratio, $O R$ odds ratio, $R H$ relative hazard, $R R$ relative risk ratio, $H C C$ hepatocellular carcinoma

of lung (adjusted HR: 0.87; 95\% CI: 0.43-1.74), colon (adjusted HR: 0.95; 95\% CI: 0.60-1.50), prostate (adjusted HR: 0.86; 95\% CI: 0.55-1.35), and breast cancer (adjusted HR: 0.85; 95\% CI: 0.57-1.25) among patients with a TSH level of $>3.5 \mathrm{mIU} / \mathrm{L}$ relative to patients with a TSH level within normal range (TSH: 0.5 to $1.4 \mathrm{mIU} /$ L). In contrast, Boursi et al. [7] reported a modest increased risk of colorectal cancer in patients with untreated hypothyroidism and $\mathrm{SCH}$ without thyroid hormone replacement compared to euthyroid patients (adjusted odds ratio [OR]: 1.16; 95\% CI: 1.08-1.24). This study also assessed the effects of levothyroxine treatment for $\mathrm{SCH}$ compared to euthyroid patients and found a protective effect of thyroid hormone replacement against colorectal cancer (adjusted OR: 0.92; 95\% CI: 0.86-0.98).
Two studies assessed the association between thyroid dysfunction and breast cancer risk. Kuijpens et al. [8] demonstrated that low levels of free T4 (fT4) are an independent risk factor for the development of breast cancer in peri- and post-menopausal women (risk of cancer in patients with low fT4 levels ( $\leq 10$ th percentile which is equivalent to $\leq 12.5$ $\mathrm{pmol} / \mathrm{L}$, OR: 2.3 ; 95\% CI: 1.2-4.6). As mentioned above, Hellevik et al. [15] found no increased risk of breast cancer in patients with hypothyroidism.

Only one study assessed the risk of prostate cancer associated with thyroid function. Mondul et al. [60] reported that hypothyroid men (i.e. inclusion of men with $\mathrm{SCH}$ and overt hypothyroidism) had a significantly reduced risk of overall prostate cancer compared to euthyroid men (adjusted OR: 0.71; 95\% CI: $0.47-1.06$ for TSH $\geq 2.2 \mathrm{mIU} / \mathrm{L}$ ). This result conflicted with that found by Hellevik et al. [15] whereby there was no 
Table 3 Quality assessment of cohort studies using the Cochrane Tool to assess the risk of bias

\begin{tabular}{|c|c|c|c|c|c|c|c|c|}
\hline $\begin{array}{l}\text { Author, } \\
\text { year }\end{array}$ & $\begin{array}{l}\text { Selection of } \\
\text { exposed and } \\
\text { non-exposed } \\
\text { from same } \\
\text { population? }\end{array}$ & $\begin{array}{l}\text { Can we be } \\
\text { confident } \\
\text { in the } \\
\text { assessment } \\
\text { of } \\
\text { exposure? }\end{array}$ & $\begin{array}{l}\text { Outcome of } \\
\text { interest was } \\
\text { not present } \\
\text { at start of } \\
\text { the study? }\end{array}$ & $\begin{array}{l}\text { The study matched exposed } \\
\text { and non-exposed for all the } \\
\text { variables associated with the } \\
\text { outcome of interest or did the } \\
\text { statistical analysis adjust for } \\
\text { these prognostic variables? }\end{array}$ & $\begin{array}{l}\text { Can we be } \\
\text { confident in the } \\
\text { assessment of } \\
\text { absence and } \\
\text { presence of } \\
\text { prognostic factors? }\end{array}$ & $\begin{array}{l}\text { Can we be } \\
\text { confident } \\
\text { in the } \\
\text { assessment } \\
\text { of } \\
\text { outcome? }\end{array}$ & $\begin{array}{l}\text { Was the } \\
\text { follow-up } \\
\text { of cohorts } \\
\text { adequate? }\end{array}$ & $\begin{array}{l}\text { Were con- } \\
\text { interventions } \\
\text { similar be- } \\
\text { tween } \\
\text { groups? }\end{array}$ \\
\hline $\begin{array}{l}\text { Kuijpens, } \\
2005 \text { [8] }\end{array}$ & DY & DY & DY & DY & DY & DY & PN & DY \\
\hline $\begin{array}{l}\text { Hellevik, } \\
2009 \text { [15] }\end{array}$ & DY & DY & DY & PY & DY & DY & PY & PY \\
\hline $\begin{array}{l}\text { Razvi, } \\
2012 \text { [16] }\end{array}$ & PY & DY & DY & PN & DY & DY & DY & PY \\
\hline $\begin{array}{l}\text { Waring, } \\
2012 \text { [64] }\end{array}$ & DY & DY & DY & PY & PY & DY & DY & PY \\
\hline $\begin{array}{l}\text { Tseng, } \\
2015 \text { [63] }\end{array}$ & PY & DY & DY & PY & DY & DY & DY & PY \\
\hline $\begin{array}{l}\text { Fighera, } \\
2015 \text { [61] }\end{array}$ & DN & DY & PN & PN/PY & DY & DY & PY & PY \\
\hline $\begin{array}{l}\text { Pinter, } \\
2017 \text { [62] }\end{array}$ & DY & DY & DY & PN & DY & DY & PY & PY \\
\hline
\end{tabular}

Abbreviations: $D Y$ definitely yes, low risk of bias, $P Y$ probably yes, $P N$ probably no, $D N$ definitely no, high risk of bias

association between the risk of prostate cancer and $\mathrm{SCH}$ or hypothyroidism. Finally, Fighera et al. [61] assessed the risk of thyroid cancer associated with thyroid function and reported an association between serum levels of TSH of $>1.64 \mathrm{mIU} / \mathrm{L}$ and thyroid malignancy (OR: 2.57; 95\% CI: 1.41-4.70).

\section{Cancer mortality}

Four articles reported cancer-related mortality outcomes [16, 62-64]. Pinter et al. [62], assessed overall survival for 667 patients with hepatocellular carcinoma and found that patients with $\mathrm{SCH}$ had a slightly decreased survival time compared to euthyroid patients (median overall survival in patients with SCH: 6.1 months; 95\% confidence interval $[\mathrm{CI}]$ : $0-13.5$ versus 10.8 months; $95 \%$ CI: 6.5-15.2). Tseng et al. [63], performed a prospective cohort study of 115,746 patients followed in Taiwan with 10 years of follow-up and reported that $\mathrm{SCH}$ was independently associated with increased risk of cancer mortality (adjusted relative risk [RR]: 1.51; 95\% CI: 1.062.15). Their study showed that the risk of cancer

Table 4 Quality assessment of case-control studies using the Newcastle -Ottawa quality assessment scale

\begin{tabular}{|c|c|c|c|c|c|c|c|c|}
\hline \multirow{2}{*}{$\begin{array}{l}\text { Author, } \\
\text { year }\end{array}$} & \multicolumn{4}{|l|}{ Selection } & \multirow{2}{*}{$\begin{array}{l}\text { Comparability } \\
\text { of cases and } \\
\text { controls }^{\mathrm{e}}\end{array}$} & \multicolumn{3}{|l|}{ Exposure } \\
\hline & $\begin{array}{l}\text { Case } \\
\text { definition } \\
\text { adequate }^{a}\end{array}$ & cases & & $\begin{array}{l}n \\
\mathrm{pls}^{\mathrm{d}}\end{array}$ & & & $\begin{array}{l}\text { Same method of } \\
\text { ascertainment for cases and } \\
\text { controls }^{9}\end{array}$ & $\begin{array}{l}\text { Non- } \\
\text { response } \\
\text { rate }^{\mathrm{h}}\end{array}$ \\
\hline & $\star$ & $\star$ & $\star$ & $\star$ & $\star \star$ & $\star$ & $\star$ & $\star$ \\
\hline $\begin{array}{l}\text { oursi, } \\
15 \text { [7] }\end{array}$ & B & $\star$ & $\star$ & $\star$ & $\star$ & $x$ & $\star$ & $\star$ \\
\hline \multicolumn{9}{|c|}{ 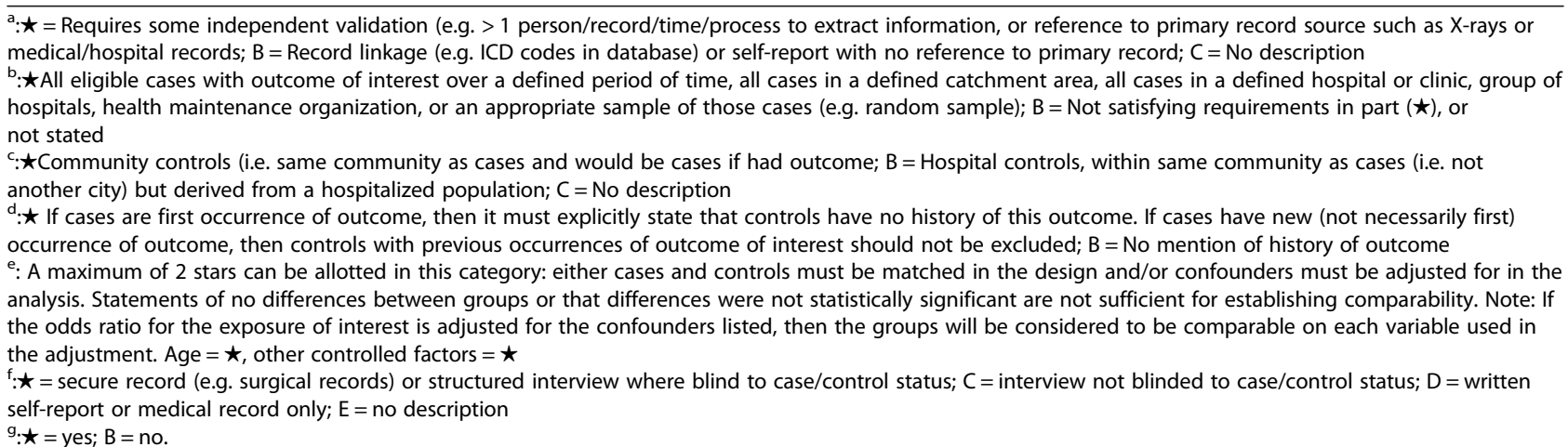 } \\
\hline
\end{tabular}


mortality among patients with SCH compared to euthyroid patients was more pronounced in bone, skin, and breast cancer. In a sub-analysis from the same study [63] restricted to patients with $\mathrm{SCH}$ defined as having $\mathrm{TSH}$ levels between 5 and $9.9 \mathrm{mIU} / \mathrm{L}$, the association between $\mathrm{SCH}$ and increased cancer-related mortality remained significant (adjusted RR: 1.61; 95\% CI: 1.12-2.31). Razvi et al. [16] conducted a retrospective cohort study using the General Practice Research Database (GPRD; since renamed the Clinical Practice Research Datalink), which is representative of patients followed in primary care in the United Kingdom. They determined that patients with $\mathrm{SCH}$ between the ages of 40 and 70 years treated with levothyroxine $(n=1634)$ had lower cancer-related mortality compared to untreated patients with $\mathrm{SCH}(n=1459)$ (adjusted hazard ratio [HR]: 0.59; 95\% CI: 0.21-0.88). Similarly, Waring et al. [64] conducted a prospective study using the Osteoporotic Fractures in Men (MrOS) study cohort which is comprised of 1587 men age $\geq 65$ years with baseline thyroid function testing. This study assessed the association between thyroid function, including $\mathrm{SCH}$ and the risk of mortality over a mean follow-up of 8.3 years. The results of this study found no association between $\mathrm{SCH}$ and the risk of cancer-related mortality compared with euthyroid men (relative hazard: 0.88 ; 95\% CI: 0.44-1.74) (Table 2).

\section{Anti-thyroperoxidase antibodies}

Only one study addressed the association between TPOAb and the risk of cancer, specifically breast cancer risk. Kuijpens et al. [8] found that TPOAb were more prevalent in women with a previous or current diagnosis of breast cancer (OR: 3.0; 95\% CI: 1.41-6.46). However, the presence of TPOAb was not associated with the development of incident in situ breast cancer during follow-up (OR: 1.1; 95\% CI: 0.4-2.7) (Table 2).

\section{Discussion}

This systematic review assessed the association between $\mathrm{SCH}$ and cancer incidence and cancer mortality. We found that $\mathrm{SCH}$ was found to be associated with an increased risk of cancer incidence specifically for colorectal and thyroid cancer and cancer-related mortality. A possible protective effect from untreated hypothyroidism against prostate cancer was also found. However, further studies are required to confirm these associations. Despite that thyroid hormone was found to have a role in breast cell proliferation, there is inconsistent evidence that thyroid function affects the risk of breast cancer. One study found no association between thyroid function and breast cancer risk [15]. Only one study showed that low levels of free T4 were an independent risk factor for breast cancer in peri- and post-menopausal women [8]. Few studies assessed the association between the presence of TPOAb and breast cancer risk with controversial results. Therefore, there is insufficient evidence to suggest whether thyroid function or TPOAb levels are associated with breast cancer risk.

Some studies have elucidated potential mechanisms in which thyroid hormone abnormalities can increase the risk of developing certain cancers [9, 65-67]. In breast cancer, it has been hypothesized that an alteration in the iodine metabolism in breast tissues could have a role in its pathogenesis since the sodium-iodine symporter is also present in breast tissue [68]. In addition, T3 can activate thyroid hormone receptors in the breast inducing cell proliferation and lobular growth in a similar fashion as estrogens [69]. In colorectal and prostate cancer, T4 and $\mathrm{T} 3$ stimulate the membrane receptor integrin $\alpha v \beta 3$, which activates some molecular pathways such as PI3-K and MAPK/ERK1/ 2, triggering cell proliferation and angiogenesis [65]. Recent animal studies have found that the use of tetraiodothyroacetic acid (tetrac), which is a thyroid hormone analogue that inhibits the activation of the membrane receptor integrin $\alpha \mathrm{v} \beta 3$ on human cancer xenografts lead to tumor regression and decreased tumor growth [70-73].

Specifically for colorectal cancer, there are two additional nuclear receptors with antagonistic effects involved: TR $\alpha 1$ and TR $\beta 1[66,67,74]$. The effect on thyroid hormones on TR $\alpha 1$ results in the stimulation of $\beta$-catenin producing cellular proliferation in the colon [74]. Conversely, TR $\beta 1$ blocks cellular proliferation when activated by thyroid hormones [67]. As such, the lack of TR $\beta 1$ expression is associated with malignant transformation in colon cancer [66]. In regards to thyroid cancer, TSH levels has been shown to be an independent clinical predictor of malignancy in thyroid nodules [75] and it is also implicated in the in vitro expression of growth factors associated with cell proliferation and angiogenesis of thyroid cells. These growth factors include the insulin-like growth factor type 1, epidermal growth factor and the vascular endothelial growth factor [55, 76, 77], which could potentially increase the risk of thyroid cancer.

To our knowledge, this is the first systematic review of the literature that analyzes the effect of $\mathrm{SCH}$ specifically on the risk of incident cancer and cancer-related mortality. Previous systematic reviews of the literature and metaanalysis focused exclusively on breast cancer [1, 2, 78], and two of these systematic reviews were focused on studying the effect of overt hypothyroidism on breast cancer $[1,78]$. Taking into consideration that overt hypothyroidism is almost always treated, these systematic reviews cannot analyze the isolated effect of the hypothyroidism itself on cancer, which constitutes a source of bias from those studies. In addition, it is difficult to determine whether their hypothyroidism persisted throughout follow-up. Furthermore, all of them included 
only cross-sectional studies $[1,2,78]$, which are temporally ambiguous and may be affected by reverse causality whereby the thyroid dysfunction is caused by the development of cancer. As acknowledged by Kuijpens et al. [8], the presence of TPOAb can be concurrent with breast cancer but their presence does not necessarily imply a risk of developing cancer in the future. This observation supports the hypothesis that the presence of concurrent TPOAb and breast cancer in cross-sectional study designs could be more related to reverse causation.

Two large cohort studies found an association between $\mathrm{SCH}$ and overall cancer-related mortality. Tseng et al. [63] performed a cohort study involving 115,746 participants and found a $2.06 \%$ cancer death rate among individuals with $\mathrm{SCH}$ versus $1.31 \%$ among euthyroid individuals $(p=0.0051)$. Consistent with this finding, Razvi et al. [16] performed a cohort study using the GPRD, involving 4735 individuals and found a $41 \%$ decreased risk of cancer related mortality among younger individuals aged 40 to 70 years who received treatment for $\mathrm{SCH}$ compared to untreated individuals with $\mathrm{SCH}$. There was no statistical significant difference in the risk of cancer related mortality among older individuals aged over 70 years with treated versus untreated $\mathrm{SCH}$. This finding is consistent with the study conducted by Waring et al. [64] which utilized data from the MrOS cohort which consists of men $\geq 65$ years. In this study, 1248 euthyroid men were compared with 89 men with subclinical hypothyroidism and there was no association between subclinical hypothyroidism and cancer mortality. These findings suggest that treatment of $\mathrm{SCH}$ or being in a euthyroid state may decrease cancer-related mortality among younger individuals. However, these studies are limited by the lack of adjustment for confounding by indication as patients with known cancer may be less likely to receive treatment for $\mathrm{SCH}$ if they have a poorer prognosis compared to a cancer patient who is less ill. Furthermore, the findings by Razvi et al. [16] and Waring et al. [64] were from a sub-analysis and the studies did not adjust for all potential confounders in the association between $\mathrm{SCH}$ and cancer-related mortality.

Our study has several strengths. We included cohort studies $[8,15,16,61-64]$ and case-control studies $[7,60]$, excluding cross-sectional studies to address the issue of reverse causality. This systematic review included studies that assessed the risk of various cancers, including the most common cancers such as colorectal, lung, prostate, and breast, and overall cancer risk. In addition, some of the included studies were large, with sample sizes larger than 20 , 000 patients $[7,15,63]$. All studies had at least 5 years of follow-up, an important consideration for studies of cancer, and potential reverse causality was addressed by excluding studies whereby the cancer diagnosis was made within 12 months of exposure assessment. The quality analysis demonstrated that the included studies had a low risk of bias. Thus, the results of the included studies provided reliable evidence for the association between thyroid dysfunction and cancer incidence and related mortality.

This systematic review had some limitations. There was a high heterogeneity of the studies, especially in terms of different risk measures and outcomes reported. Consequently, we were unable to perform a meta-analysis. Moreover, some of the studies combined individuals with SCH and overt hypothyroidism [7, 8, 15, 60-62], decreasing the strength to the conclusions on the role of $\mathrm{SCH}$ in cancer pathogenesis. Furthermore, the study by Pinter et al. [62] diagnosed $\mathrm{SCH}$ on the basis of T4 levels, which is different from the definition of $\mathrm{SCH}$ used in the other studies. As such, there was heterogeneity in the definition of SCH between studies. Finally, there may be publication bias whereby studies with null findings are not published.

\section{Conclusions}

In summary, $\mathrm{SCH}$ may be associated with an increased risk of colorectal and thyroid cancer. Treatment of $\mathrm{SCH}$ may be associated with a decreased risk of cancerrelated mortality among younger individuals. Overall, there is a paucity of studies addressing the association between $\mathrm{SCH}$ and incident cancer risk and cancer mortality. Given the difference of cancer pathophysiology in various cancers, further studies are needed to assess the association between untreated $\mathrm{SCH}$ and the risk of different individual cancers.

\section{Supplementary information}

Supplementary information accompanies this paper at https://doi.org/10. 1186/s12902-020-00566-9.

\section{Additional file 1.}

\section{Abbreviations}

Cl: Confidence interval; GPRD: General Practice Research Database;

HR: Hazards ratio; MrOS: Osteoporotic Fractures in Men; OR: Odds ratio; RR: Relative risk; RXR: Retinoid X receptor; SCH: Subclinical hypothyroidism; T3: Triiodothyronine; T4: Thyroxine; TPOAb: Anti-thyroperoxidase antibodies; TSH: Thyroid stimulating hormone

\section{Acknowledgements}

Not applicable.

\section{Authors' contributions}

All authors contributed to the study design and writing of the manuscript. J.G. performed the literature search. J.G. and O.Y. performed the screening of articles to be included in the systematic review, data extraction and quality analyses of studies. K.B.F. was the third reviewer who resolved any conflicts that arose during the screening of articles, data extraction, and quality analyses. All authors (J.G., O.Y., K.B.F., J.F.B., L.A., M.P.) contributed to study design, interpretation of data, and reviewed and approved the final manuscript. O.Y. is the guarantor of this work, had full access to the data and takes responsibility for the integrity of the data and data analyses.

\section{Funding}

Dr. Yu, Dr. Filion and Dr. Azoulay hold salary support from the Fonds de recherche du Québec - Santé (FRQS). Both Drs. Filion and Azoulay are 
recipients of William Dawson Scholar Awards from McGill University. The funding support given to the investigators of this study had no role in the study design, conduct or reporting.

\section{Availability of data and materials}

Not applicable.

\section{Ethics approval and consent to participate}

Not applicable.

\section{Consent for publication}

Not applicable.

\section{Competing interests}

No conflict of interests to declare.

\section{Author details}

'Department of Family Medicine, McGill University, Montreal, Quebec, Canada. ${ }^{2}$ Division of Clinical Epidemiology, Department of Medicine, McGill University, Montreal, Quebec, Canada. ${ }^{3}$ Center for Clinical Epidemiology, Lady Davis Institute, Jewish General Hospital, 3755 Côte Sainte-Catherine, H-425, Montreal, Quebec H3T 1E2, Canada. ${ }^{4}$ Department of Epidemiology, Biostatistics, and Occupational Health, McGill University, Montreal, Quebec, Canada. ${ }^{5}$ Gerald Bronfman Department of Oncology, McGill University, Montreal, Quebec, Canada. ${ }^{6}$ Department of Oncology, McGill University, Montreal, Quebec, Canada. ${ }^{7}$ Segal and Goodman Cancer Centres of McGill University, Montreal, Quebec, Canada. ${ }^{8}$ Division of Endocrinology, Department of Medicine, Jewish General Hospital, Montreal, Quebec, Canada.

Received: 2 October 2019 Accepted: 2 June 2020

Published online: 09 June 2020

\section{References}

1. Angelousi AG, Anagnostou VK, Stamatakos MK, Georgiopoulos GA, Kontzoglou KC. Mechanisms in endocrinology: primary HT and risk for breast cancer: a systematic review and meta-analysis. Eur J Endocrinol. 2012; 166(3):373-81.

2. Shi XZ, Jin X Fau - Xu P, Xu P Fau - Shen H-M, Shen HM. Relationship between breast cancer and levels of serum thyroid hormones and antibodies: a meta-analysis. Asian Pac J Cancer Prev 2014;15(16):6643-6647.

3. Pascual A, Aranda A. Thyroid hormone receptors, cell growth and differentiation. Biochim Biophys Acta. 2013;1830(7):3908-16.

4. Surks MI, Ortiz E, Daniels GH, Sawin CT, Col NF, Cobin RH, et al. Subclinical thyroid disease: scientific review and guidelines for diagnosis and management. JAMA. 2004;291(2):228-38 Epub 2004/01/15.

5. Bielecka-Dabrowa A, Godoy B, Suzuki T, Banach M, von Haehling S. Subclinical hypothyroidism and the development of heart failure: an overview of risk and effects on cardiac function. Clin Res Cardiol. 2018; 108(3):225-33 Epub 2018/08/10.

6. Garber JR, Cobin RH, Gharib H, Hennessey JV, Klein I, Mechanick Jl, et al. Clinical practice guidelines for hypothyroidism in adults: cosponsored by the American Association of Clinical Endocrinologists and the American Thyroid Association. Thyroid. 2012;22(12):1200-35 Epub 2012/09/08.

7. Boursi B, Haynes K, Mamtani R, Yang YX. Thyroid dysfunction, thyroid hormone replacement and colorectal cancer risk. J Natl Cancer Inst. 2015; 107(6):djv084 Epub 2015/04/10

8. Kuijpens JL, Nyklictek I, Louwman MW, Weetman TA, Pop VJ, Coebergh JW. Hypothyroidism might be related to breast cancer in post-menopausal women. Thyroid. 2005;15(11):1253-9 Epub 2005/12/17.

9. Giustarini E, Pinchera A, Fierabracci P, Roncella M, Fustaino L, Mammoli C, et al. Thyroid autoimmunity in patients with malignant and benign breast diseases before surgery. Eur J Endocrinol. 2006;154(5):645-9.

10. Biondi B, Cooper DS. The clinical significance of subclinical thyroid dysfunction. Endocr Rev. 2008:29(1):76-131.

11. Higgins JPT GSe. Cochrane Handbook for Systematic Reviews of Interventions Version 5.1.0 [updated March 2011]. The Cochrane Collaboration, 2011E. Available from www.handbook.cochrane.org.

12. Stang A. Critical evaluation of the Newcastle-Ottawa scale for the assessment of the quality of nonrandomized studies in meta-analyses. Eur J Epidemiol. 2010;25(9):603-5 Epub 2010/07/24.
13. Moher D, Altman DG, Liberati A, Tetzlaff J. PRISMA statement. Epidemiology. 2011;22(1):128 author reply.

14. Moher D, Shamseer L, Clarke M, Ghersi D, Liberati A, Petticrew M, et al. Preferred reporting items for systematic review and meta-analysis protocols (PRISMA-P) 2015 statement. Syst Rev. 2015;4:1.

15. Hellevik Al, Asvold BO, Bjoro T, Romundstad PR, Nilsen TI, Vatten LJ. Thyroid function and cancer risk: a prospective population study. Cancer Epidemiol Biomark Prev. 2009;18(2):570-4 Epub 2009/01/22.

16. Razvi S, Weaver JU, Butler TJ, Pearce SH. Levothyroxine treatment of subclinical hypothyroidism, fatal and nonfatal cardiovascular events, and mortality. Arch Intern Med. 2012;172(10):811-7 Epub 2012/04/25.

17. Al-Bader A, Zawawi F, Singer Z, Mlynarek A, Hier M, Tamilia M, et al. Preoperative TSH and thyroglobulin levels: would it predict thyroid cancer? Otolaryngol Pol. 2015;69(3):21-5.

18. Calvo RM, Roda JM, Obregon MJ. Morreale de Escobar G. thyroid hormones in human tumoral and normal nervous tissues. Brain Res. 1998;801(1-2): 150-7.

19. Mu G, Mu X, Xing H, Xu R, Sun G, Dong C, et al. Subclinical hypothyroidism as an independent risk factor for colorectal neoplasm. Clin Res Hepatol Gastroenterol. 2015;39(2):261-6 Epub 2014/09/23.

20. Reddy A, Dash C, Leerapun A, Mettler TA, Stadheim LM, Lazaridis KN, et al. Hypothyroidism: a possible risk factor for liver cancer in patients with no known underlying cause of liver disease. Clin Gastroenterol Hepatol. 2007; 5(1):118-23 Epub 2006/09/30.

21. Abe R, Hirosaki A, Kimura M. Pituitary-thyroid function in patients with breast cancer. Tohoku J Exp Med. 1980;132(2):231-6.

22. Aldinger KA, Schultz PN, Blumenschein GR, Samaan NA. Thyroid-stimulating hormone and prolactin levels in breast cancer. Arch Intern Med. 1978; 138(11):1638-41.

23. Chiappa C, Rovera F, Rausei S, Del Ferraro S, Fachinetti A, Lavazza M, et al. Breast cancer and thyroid diseases: analysis of 867 consecutive cases. J Endocrinol Investig. 2017:40(2):179-84.

24. Dessaint JP, Lefebvre J, Adenis L, Wemeau JL, Linquette M. Serum T4, T3, rT3 and T.S.H. concentration in cancer (author's transl). Ann Endocrinol (Paris). 1978;39(1):73-4 Epub 1978/01/01. Concentration sanguine de la T4, de la T3, de la rT3 et de la T.S.H. chez des cancereux.

25. Ditsch N, Liebhardt S, Von Koch F, Lenhard M, Vogeser M, Spitzweg C, et al. Thyroid function in breast cancer patients. Anticancer Res. 2010;30(5):1713-7 Epub 2010/07/02.

26. Ellerhorst JA, Cooksley CD, Grimm EA. Autoimmunity and hypothyroidism in patients with uveal melanoma. Melanoma Res. 2001;11(6):633-7.

27. Hajtmanova E, Murin P, Kinclova I, Hajtman A, Pec M, Kostkova L, et al. [thyroid disorders in women with breast cancer]. Klin Onkol. 2012;25(2):1249. Epub 2012/04/27. Tyreopatie u zien s karcinomom prsnika.

28. Kim HK, Yoon JH, Kim SJ, Cho JS, Kweon SS, Kang HC. Higher TSH level is a risk factor for differentiated thyroid cancer. Clin Endocrinol. 2013;78(3):472-7.

29. Kohler AH, Kuhnel W, Kilz F. Breast cancer and TRH -- response. Arch Geschwulstforsch. 1981;51(3):273-8 Epub 1981/01/01.

30. Lehrer S, Diamond EJ, Stone NN, Stock RG. Serum thyroid-stimulating hormone is elevated in men with Gleason 8 prostate cancer. BJU Int. 2005; 96(3):328-9.

31. Michalaki V, Kondi-Pafiti A, Gennatas S, Antoniou A, Primetis H, Gennatas C. Breast cancer in association with thyroid disorders. J buon. 2009;14(3):425-8 Epub 2009/10/08.

32. Mourouzis I, Tzovaras A, Armonis B, Ardavanis A, Skondra M, Misitzis J, et al. Are thyroid hormone and tumor cell proliferation in human breast cancers positive for HER2 associated? Int J Endocrinol. 2015;2015:765406.

33. Oba J, Esmaeli B, Ellerhorst JA, Lyons GR, Milton DR, Wang WL, et al. Trends in hepatocyte growth factor, insulin-like growth factor 1, thyroid-stimulating hormone, and leptin expression levels in uveal melanoma patient serum and tumor tissues: correlation to disease progression. Melanoma Res. 2017;27(2):126-33.

34. Ozemir IA, Gurbuz B, Bayraktar B, Aslan S, Baskent A, Yalman H, et al. The effect of thyroid-stimulating hormone on tumor size in differentiated thyroid carcinoma. Indian J Surg. 2015;77(Suppl 3):967-70.

35. Perry M, Goldie DJ, Self M. Thyroid function in patients with breast cancer Ann R Coll Surg Engl. 1978;60(4):290-3 Epub 1978/07/01.

36. Rose DP, Davis TE. Plasma triiodothyronine concentrations in breast cancer. Cancer. 1979:43(4):1434-8.

37. Saraiva PP, Figueiredo NB, Padovani CR, Brentani MM, Nogueira CR. Profile of thyroid hormones in breast cancer patients. Braz J Med Biol Res. 2005; 38(5):761-5. 
38. Turken O, Narln Y, Demlrbas S, Onde ME, Sayan O, Kandemlr EG, et al. Breast cancer in association with thyroid disorders. Breast Cancer Res. 2003; 5(5):R110-3.

39. Brinton LA, Hoffman DA, Hoover R, Fraumeni JF Jr. Relationship of thyroid disease and use of thyroid supplements to breast cancer risk. J Chronic Dis. 1984;37(12):877-93.

40. Cornelli U, Belcaro G, Recchia M, Finco A. Levothyroxine and lung cancer in females: the importance of oxidative stress. Reprod Biol Endocrinol. 2013;11:75.

41. Shering SG, Zbar AP, Moriarty M, McDermott EW, O'Higgins NJ, Smyth PP. Thyroid disorders and breast cancer. Eur J Cancer Prev. 1996;5(6):504-6 Epub 1996/12/01.

42. Vural O, Dizdar O, Petekkaya I, Alnak A, Babacan T, Altundag K. Frequency of thyroid disease among breast cancer patients: a descriptive study of breast cancer patients. J buon. 2013;18(1):294-5 Epub 2013/04/25

43. Cristofanilli M, Yamamura Y, Kau SW, Bevers T, Strom S, Patangan M, et al. Thyroid hormone and breast carcinoma. Primary hypothyroidism is associated with a reduced incidence of primary breast carcinoma. Cancer. 2005;103(6):1122-8 Epub 2005/02/16.

44. Goldman MB, Monson RR, Maloof F. Cancer mortality in women with thyroid disease. Cancer Res. 1990;50(8):2283-9.

45. Khan SR, Chaker L, Ruiter R, Aerts JG, Hofman A, Dehghan A, et al. Thyroid function and Cancer risk: the Rotterdam study. J Clin Endocrinol Metab. 2016;101(12):5030-6.

46. Mellemgaard A, From G, Jorgensen T, Johansen C, Olsen JH, Perrild H. Cancer risk in individuals with benign thyroid disorders. Thyroid. 1998;8(9):751-4

47. Rinaldi S, Plummer M, Biessy C, Tsilidis KK, Ostergaard JN, Overvad K, et al. Thyroidstimulating hormone, thyroglobulin, and thyroid hormones and risk of differentiated thyroid carcinoma: the EPIC study. J Natl Cancer Inst. 2014;106(6):dju097.

48. Sogaard M, Farkas DK, Ehrenstein V, Jorgensen JO, Dekkers OM, Sorensen HT. Hypothyroidism and hyperthyroidism and breast cancer risk: a nationwide cohort study. Eur J Endocrinol. 2016;174(4):409-14.

49. Li JZ, Jin YJ, Liu X, Zhang LY. Association between the serum TSH concentration and thyroid cancer incidence. Zhonghua Zhong Liu Za Zhi. 2011;33(12):921-4 Epub 2012/02/22

50. Adami HO, Rimsten A, Thoren L, Vegelius J, Wide L. Thyroid disease and function in breast cancer patients and non-hospitalized controls evaluated by determination of TSH, T3, rT3 and T4 levels in serum. Acta Chir Scand. 1978;144(2):89-97 Epub 1978/01/01.

51. Tosovic A, Becker C, Bondeson AG, Bondeson L, Ericsson UB, Malm J, et al. Prospectively measured thyroid hormones and thyroid peroxidase antibodies in relation to breast cancer risk. Int J Cancer. 2012;131(9):2126-33 Epub 2012/02/11

52. Hassan MM, Kaseb A, Li D, Patt YZ, Vauthey JN, Thomas MB, et al. Association between hypothyroidism and hepatocellular carcinoma: a casecontrol study in the United States. Hepatology. 2009;49(5):1563-70.

53. Simon MS, Tang MT, Bernstein L, Norman SA, Weiss L, Burkman RT, et al. Do thyroid disorders increase the risk of breast cancer? Cancer Epidemiol Biomark Prev. 2002;11(12):1574-8 Epub 2002/12/24.

54. Weiss HA, Brinton LA, Potischman NA, Brogan D, Coates RJ, Gammon MD, et al. Breast cancer risk in young women and history of selected medical conditions. Int J Epidemiol. 1999;28(5):816-23.

55. Hoffmann S, Hofbauer LC, Scharrenbach V, Wunderlich A, Hassan I, Lingelbach $\mathrm{S}$, et al. Thyrotropin (TSH)-induced production of vascular endothelial growth factor in thyroid cancer cells in vitro: evaluation of TSH signal transduction and of angiogenesis-stimulating growth factors. J Clin Endocrinol Metab. 2004;89(12):6139-45.

56. Kalache A, Vessey MP, McPherson K. Thyroid disease and breast cancer: findings in a large case-control study. Br J Surg. 1982;69(7):434-5.

57. Sandhu MK, Brezden-Masley C, Lipscombe LL, Zagorski B, Booth GL. Autoimmune hypothyroidism and breast cancer in the elderly. Breast Cancer Res Treat. 2009;115(3):635-41.

58. Shah M, Orengo IF, Rosen T. High prevalence of hypothyroidism in male patients with cutaneous melanoma. Dermatol Online J. 2006;12(2):1 Epub 2006/04/28.

59. Rosenberg AG, Dexeus F, Swanson DA, von Eschenbach AC. Relationship of thyroid disease to renal cell carcinoma. An epidemiologic study. Urology. 1990;35(6):492-8.

60. Mondul AM, Weinstein SJ, Bosworth T, Remaley AT, Virtamo J, Albanes $D$. Circulating thyroxine, thyroid-stimulating hormone, and hypothyroid status and the risk of prostate cancer. PLoS One. 2012;7(10):e47730 Epub 2012/11/03
61. Fighera $T M$, Perez CL, Faris N, Scarabotto PC, da Silva TT, Cavalcanti TC, et al. TSH levels are associated with increased risk of thyroid carcinoma in patients with nodular disease. Endokrynol Pol. 2015;66(6):480-5.

62. Pinter M, Haupt L, Hucke F, Bota S, Bucsics T, Trauner M, et al. The impact of thyroid hormones on patients with hepatocellular carcinoma. PLoS One. 2017;12(8):e0181878.

63. Tseng FY, Lin WY, Li Cl, Li TC, Lin CC, Huang KC. Subclinical hypothyroidism is associated with increased risk for cancer mortality in adult Taiwanese-a 10 years population-based cohort. PLoS One. 2015;10(4):e0122955 Epub 2015/04/02.

64. Waring AC, Harrison S, Samuels MH, Ensrud KE, Le BES, Hoffman AR, et al. Thyroid function and mortality in older men: a prospective study. J Clin Endocrinol Metab. 2012;97(3):862-70 Epub 2012/01/13.

65. Pinto $M$, Soares $P$, Ribatti $D$. Thyroid hormone as a regulator of tumor induced angiogenesis. Cancer Lett. 2011;301(2):119-26.

66. Markowitz S, Haut M, Stellato T, Gerbic C, Molkentin K. Expression of the ErbA-beta class of thyroid hormone receptors is selectively lost in human colon carcinoma. J Clin Invest. 1989;84(5):1683-7.

67. Horkko TT, Tuppurainen K, George SM, Jernvall P, Karttunen TJ, Makinen MJ. Thyroid hormone receptor beta 1 in normal colon and colorectal cancerassociation with differentiation, polypoid growth type and K-ras mutations. Int J Cancer. 2006;118(7):1653-9.

68. Kilbane MT, Ajjan Ra W, A. P., Weetman Ap D, R, McDermott, E. W, McDermott Ew, O'Higgins, N. J., O'Higgins Nj S, P. P. Tissue iodine content and serum-mediated 1251 uptake-blocking activity in breast cancer. J Clin Endocrinol Metab. 2000;85(3):1245-50.

69. Conde I, Paniagua R, Zamora J, Blanquez MJ, Fraile B, Ruiz A, et al. Influence of thyroid hormone receptors on breast cancer cell proliferation. Ann Oncol. 2006;17(1):60-4.

70. Lin HY, Sun M, Tang HY, Lin C, Luidens MK, Mousa SA, et al. L-Thyroxine vs. 3,5,3'-triiodo-L-thyronine and cell proliferation: activation of mitogenactivated protein kinase and phosphatidylinositol 3-kinase. Am J Phys Cell Phys. 2009;296(5):C980-91 Epub 2009/01/23.

71. Yalcin M, Bharali DJ, Lansing L, Dyskin E, Mousa SS, Hercbergs A, et al. Tetraidothyroacetic acid (tetrac) and tetrac nanoparticles inhibit growth of human renal cell carcinoma xenografts. Anticancer Res. 2009;29(10):3825-31 Epub 2009/10/23

72. Yalcin M, Dyskin E, Lansing L, Bharali DJ, Mousa SS, Bridoux A, et al. Tetraiodothyroacetic acid (tetrac) and nanoparticulate tetrac arrest growth of medullary carcinoma of the thyroid. J Clin Endocrinol Metab. 2010;95(4): 1972-80 Epub 2010/02/06

73. Hercbergs AH, Ashur-Fabian O, Garfield D. Thyroid hormones and cancer: clinical studies of hypothyroidism in oncology. Curr Opin Endocrinol Diabetes Obes. 2010;17(5):432-6 Epub 2010/08/07.

74. Kress E, Skah S, Sirakov M, Nadjar J, Gadot N, Scoazec JY, et al. Cooperation between the thyroid hormone receptor TRalpha1 and the WNT pathway in the induction of intestinal tumorigenesis. Gastroenterology. 2010;138(5):1863-74.

75. Boelaert K, Horacek J, Holder RL, Watkinson JC, Sheppard MC, Franklyn JA. Serum thyrotropin concentration as a novel predictor of malignancy in thyroid nodules investigated by fine-needle aspiration. J Clin Endocrinol Metab. 2006;91(11):4295-301 Epub 2006/07/27.

76. Eggo MC, Bachrach LK, Burrow GN. Interaction of TSH, insulin and insulinlike growth factors in regulating thyroid growth and function. Growth Factors. 1990;2(2-3):99-109.

77. Westermark K, Karlsson FA, Westermark B. Thyrotropin modulates EGF receptor function in porcine thyroid follicle cells. Mol Cell Endocrinol. 1985; 40(1):17-23.

78. Hardefeldt PJ, Eslick GD, Edirimanne S. Benign thyroid disease is associated with breast cancer: a meta-analysis. Breast Cancer Res Treat. 2012;133(3): 1169-77.

\section{Publisher's Note}

Springer Nature remains neutral with regard to jurisdictional claims in published maps and institutional affiliations. 